\title{
MUSLIM SOCIETY BETWEEN FUNDAMENTALISM AND LIBERALISM: THE PROBLEM OF CIVIL SOCIETY*
}

\author{
Yu.M. Pochta \\ Peoples' Friendship University of Russia (RUDN University) \\ Miklukho-Maklaya str., 10/2, Moscow, Russia, 117198
}

The author examines the issue of civil society in the Muslim world in general and in Russia in particular. It received a special significance after the Cold War, when liberal democracy and the concept of civil society were proclaimed as universal models, able to explain features of the modernization process. Research and practical realization of this process in non-Western societies is strongly influenced by the identification of the institution of civil society with the Western post-Christian civilization, with liberal political culture. However, historical experience shows that civil society cannot be transferred from a different social environment, it must grow on its own culture. This totalizing universalistic thinking and the functionalist-evolutionist modernization approaches are not conducive to finding an answer to the question of the existence of civil society in non-Western societies. It needs a civilizational approach, a historical analysis of cultural contexts of occurring processes of modernization, establishing a market economy, democratic political regimes and civil society. The contemporary postmodern discourse supposes civilizational multiplicity of political modernity and political modernization process. The key in these circumstances is a question about the peculiarities of the coexistence in the modern world societies at different stages of social development. In particular, it is necessary to take into account the possible coexistence of several pre secular cultures (Islamic, Confucian) and liberal democracy as post secular phenomenon.

Key words: civil society, civilization, democracy, liberalism, modernization, post secular society, Muslim society, fundamentalism

At the end of XX and at the beginning of XXI century the multi-version transition to democracy in the post-Soviet area, in Latin America, Asia and Africa inspired politicians and scholars to consider the concept of civil society as a model allowing explaining specific features of modernization process. It is considered, that the formation of modern civil society relates to democratization, because both of these processes limit domination of the state. When civil society is developed its relations with the state have a balanced character. If civil society is not developed enough, then the state absorbs it and exercise a part of its functions in its own way. When civil society is weak the state expands its authorities, usually at the expense of rights and freedoms of citizens. Demo-

* Данная статья была впервые опубликована в 2011 г. в коллективной монографии, подготовленной участниками международной конференции "Religions in the Public Spheres" (June 24-26, 2010, Institute of Philosophy, Adam Mickiewicz University, Poznan, Poland): Yuriy M. Pochta. Muslim Society between Fundamentalism and Liberalism: the Problem of Civil Society // Religions in the Public Spheres / Tadeusz Buksinski (éd.). (Dia-Logos. Studies in Philosophy and Social Sciences. Bd./Vol. 14). Frankfurt am Main: Internationaler Verlag der Wissenschaften, 2011. P. 367-379. 
cracy as the rule of people (of majority) can be declared by stipulating it in the constitution and electoral laws. In case of civil society it is more complicated, because civil society characterizes abilities of society to self-organization and the presence of a number of freedoms and ethical grounds, first of all the idea of justice.

History of humankind approved, that civil society could not be transferred from other social environments. It needs to grow up (it can be supported in growing) on the grounds of its own culture. But the institution of civil society should not be idealized, because while uniting and organizing mutual activity people can pursue both positive (democratic), and negative (narrow group - mafia, extremist) objectives. Weakness of the state is not always a benefit and the evidence of successful civil society institutions.

Identification of the civil society institution with the Western post-Christian civilization, with liberal political culture has a strong impact on studies and practical realization of this process in the non-Western societies. With respect to other civilizations, in particular, some authors express opinions on full absence of civil society or of its under development (S. Huntington, E. Gellner). F. Fukuyama recognizes that Islam is a serious rival of liberalism and claims the status of universal doctrine, because it has in possession the systematic and consistent ideology with its own moral code, as well as the doctrine of political and social justice. Liberal democracy was defeated by Islam as by its authoritarian alternative in many Muslim countries, where the fifth part of humankind live, although carried over many representatives of the Muslim elite in power. One of the reasons for modern Islamic fundamentalism arising was a protective response from the side of traditional Islamic society to the intrusion of the Western liberal values and because of economic collapse in many Muslim countries. And yet Islam cannot be a real competitor of the liberal project, because in the long-term perspective Islam will not be able to compete with liberal democracy on the territory of democracy. The Islamic world will be more influenced by liberal ideas, than the Western world by Islamic ideas [5. P. 89-90].

F. Fukuyama considers that the establishment of liberal democracy in Muslim society can be blocked by religion by resisting the transformation of traditional religious values into the values of democratic or civilian culture, conceptualized by such concepts as secularism, rationality, empathy and tolerance. If between Christianity and liberal democracy there is no inner conflict, and most of the modern democracies exist in secular post-Christian societies, then fundamentalist Islam belongs to totalitarian religions and assumes, in particular, interference of religion with politics. Recognizing that Islam can be compatible with democracy, alongside with that Fukuyama claims, that it can be hardly agreed with liberalism and recognition of human rights, in particular, with the right to liberty of conscience. The only exception is Turkey, which is «the only country in the early XX century explicitly rejected the Islamic heritage in favor of secular society» [5. P. 329].

It is difficult to agree with F. Fukuyama with reference to liberal democratic and secular character of the modern Turkish society. Formally in this country the institutions of democratic political regime are founded, citizen rights and freedoms are being declared, institutions of civil society exist. But in practice the undivided reluctance of the EC member states to accept Turkey suggests otherwise. Fukuyama does not pay attention 
to the formation after the $2^{\text {nd }}$ World War in Western Europe large communities of immigrants from Muslim countries, which also have a remarkable influence on democratization processes during transition from secular society to post-secular society. Interrelations of native population and Muslims assume particular significance, when political and social competition among social groups of different religious identification is sharpening. In this context the concept of Intra-European Christian-Muslim frontier was originated. It means quite a common situation for modern Europe, when the contacts of local (conditionally «Christian») population and Muslims (with local citizenship and guestworkers) takes place at the boundaries of streets, squares and houses. At these frontiers the interaction of religions, legal and political cultures, ways of living is taking place. This is the practical result of failing to assimilate Muslims, when quantitative proportion and organization of interacting social groups is of great importance. As J. Habermas writes, «own, "home", confessions, in fact, gain greater authority because of appearance and viability of "alien" religious communities. If to refer to the experience typical for Netherlands or Germany, Muslim neighbors make their Christian fellow citizens meeting the competing faith. By this they make secular-minded citizens clearly recognize the phenomena of religion, publicly manifested itself» [6].

It may be supposed, that Christianity will have to be mobilized to revise its positions within the space of post-secular society, populated both by secularized people, and immigrants from pre-secular societies. The Islamic challenge is able to give a new impulse for renovating Christianity, resembling what happened in the Middle Ages, when the concept of Christian world had been formed as a result of centuries-long opposition of Christian and Muslim societies.

We conclude, that the West- (Euro-) centric approach does not reflect the existing realities. It does not allow answering the question of existence (possibility of existence) of civil society in societies of other civilizations. Here historical approach, civilizational analysis of the cultural context of modernization, development of market-based economy, democratic political regimes and civil society are required. Also it is required to consider the fact that the origin of «Easternization» concept as a «civilizational» alternative of Westernization suggests, that the relation between Westernization and modernization ceases to look like unconditional.

Under such conditions the problem of compatibility of pre-secular cultures (Islamic, Confucian) and liberal democracy becomes the key problem. Supporters of a positive answer to this question proceed from the premise, that the modernist Euro-centric view of world history, treated as linear, unidirectional and progressive should be abandoned. They are more prone to the postmodern approach to history, which underlines significance of the spiritual grounds of human existence, providing the concept of mankind unity not through unification, but through communicative difference, through dialogue of cultures and civilizations. In philosophical thought it appears in declining universal form of rationality and in recognizing the existence of different national traditions in history of philosophy. Coexistence of different nations, dialogue of their cultures become possible through recognizing their considerable specificity in order to overcome the established stereotypes, expressed in the opposition of authoritarian East and democratic West, faith and reason, traditionalism and modernism. The coexistence of different na- 
tions and dialogue of their cultures becomes possible through recognizing their considerable specificity in order to overcome the established stereotypes expressed in the opposition of the authoritarian East and democratic West, faith and reason, traditionalism and modernism. The contemporary postmodern discourse supposes civilizational multiplicity of political modernity and the political modernization process $[10$. P. $35-57$; 19. P. 49-66].

There is also a point of view, that democratic development has many forms, because each culture is capable to create its own model of democratic mode. It is supposed also, that religious democracy can exist, including Islamic democracy, which does not comply with the Western liberal model [4]. Also there are assertions that democracy already exists in Muslim world and is realized by means of such concepts of traditional Islam, as shura (consultations), ijma (consensus) and ijtihad (independent authoritative interpretation). A number of Islamic theorists and politicians can be attributed to the adherents of the Islamic democracy concept (M. Iqbal, Hassan al-Turabi, Ali Shariati, Mohammad Khatami). They believe that Islam creates conditions for integrating democracy and spirituality. Also there is the Islamic concept of «Theo-Democracy» (Abu al-Maududi). Bassam Tibi considers, that for adjusting Islam and civil society it is required to realize Islamic cultural acceptance of political culture of democracy. The idea of civil society, combined with culture of democracy, and the Islamist concept of Allah supremacy are in competition with each other. Islamists can also declare that the civil society concept does not comply with Islamic concepts [2; 22].

According to Shireen Hunter the reason for different opinions in the discussions on compatibility of Islam and Western ideas, is in an abstract, static and unhistorical approach to the role and position of Islam in organizing Muslim societies. Outside of the specific frameworks of space and time it is not possible «to determine abstractly compatibility of Islam and democracy: convincing arguments can be provided by each side. The fact is that development and consolidation of democratic systems suppose the existence of many social-economic conditions, but not only adherence to secularism. Many modern governments, which can be characterized as secular, totalitarian or authoritarian, can be examples of that» [7. P. 16].

Western critics of this approach accuse their opponents, that they do relative the concept of democracy, and at the same time misrepresent the real content of Islamic concepts of shura, ijma and ijtihad, trying to adjust them to the modern realities. They claim that the concept of Islamic democracy, where in fact God's sovereignty excludes sovereignty of people, is an antithesis of the secular concept of Western democracy. Moreover, they believe that Muslim law, the rule of which is supposed to be over all sides of society life, cannot provide to all citizens their equality before the law, regardless of religious and gender belonging. Quite often they name modern Iran as an example, where according to the critics of Islamic democracy, Islamists constrain democratic processes and destroy civil society.

Politicians and scholars debate a lot about the necessity of democratic development in Muslim world. But who needs democracy in Muslim world and who may be called the moving force of this process? Two of the main actors in world policy — USA and $\mathrm{EU}$ - are full of desire to promote the process of transiting Muslim world (in particular 
Arab countries) from the authoritarianism to democratic forms of governing. Neither China, nor Russia displays any activity in this direction, while developing actively relations with Muslim countries.

During the Post-Soviet period the West, facing such an obstacle of globalization, as underdevelopment of social-economic life and authoritarianism of the non-Western world, seeks ways to help to accelerate modernization, including democratization and creation of civil society. Formally in many non-Western countries democratic regimes exist, though they often cover authoritarian government. They can be named as «liberalized autocracies» with regular elections, similarity of multi-party system, with declaring support of universal human rights, with a positive attitude to anti-corruption and democracy development programs, financed by the West. But often these processes are performances in the «theatre of democratization». Accepting certain manifestations of democracy, the governing regimes exclude an opportunity for opposition to become a real participant of political life [16. P. 103]. In these societies civil society is under the state control and, as a rule, does not appear on the political scene. The West can promptly help to organize and hold elections in a non-Western country, but they do not mean the final triumph of democracy. They can even worsen the situation and strengthen positions of fundamentalists, because they are usually better organized, and citizens are not able to accept responsible voting decisions in full (Iran, Algeria, Turkey, and Palestine).

Islamists use legal and illegal methods of straggling for power. A number of movements have a positive attitude to active participation in legal political process (creating alliances with other political movements, participation in public discussions, proposing their own interpretation of democracy, human rights, rule of law). They often take an active part in political activities, trying to come to power, gradually becoming familiar with democratic forms and entering discussions on human rights problems. If failed they transfer their political activity to the structures of civil society (religious, social, professional organizations).

In general adherents of an optimistic constructivist approach to the problem of developing democracy in Muslim countries consider that advocates of democracy should achieve such simple goals, as development of civil society in non-Western societies. Elections under such conditions are not the beginning of democratic process, but its final, a signal that civil society already created. As Daniel Pipes writes, «Washington should actively help Muslim countries navigate from autocracy to democracy without passing through an Islamist phase. This is indeed achievable. As I wrote a decade ago in response to the Algerian crisis, instead of focusing on quick elections, which almost always benefit the Islamists, the American government should shift its efforts to slower and deeper goals: "political participation, the rule of law (including an independent judiciary), freedom of speech and religion, property rights, minority rights, and the right to form voluntary organizations (especially political parties)". Elections should only follow on the achievement of these steps. Realistically, they could well take decades to achieve. Elections should culminate the democratic process, not start it. They ought to celebrate civil society successfully achieved. Once such a civil society exists (as it does in Iran but not in Algeria), voters are unlikely to vote Islamists into power» [17]. 
In this regard the European Union experience is quite interesting. It relates to analyzing possibilities and consequences of European cooperation with moderate Islamists in promoting democracy in the Middle East region as the way of using «soft power». It is considered, that the present authoritarian regimes are the main barrier to the reforms, because they try to avoid true democratic reforms. However a political reform cannot be effective without integrating moderate Islamists in this process. The EU approach to political reforms in the Middle East region is in taking into account the current circumstances at the local level. And the real situation is that political reforms can't be effective without gradual integration of nonviolent Islamic groups. In order to minimize the risks interaction with political Islam should be a part of more broad EU strategy, aimed to promote democracy in the region with the provision for civilizational context of political life. Moderate Islamists would expect European support in conducting political reforms, which would allow providing a true representation of the will of people by peaceful means in the near future.

One of the recommendations of the final report on EU strategic partnership with the Mediterranean and Middle East countries calls for EU cooperation «with nonviolent political organizations and movements of civil society on all social levels, for open cooperation with all organizations, committed to nonviolent and democratic means». This statement offers opportunities for EU interaction with moderate Islamist groups, which practice not violence, but peaceful means to achieve their goals. During last almost ten years the EU implemented its various initiatives both on the state level, and on the level of Arab civil society. The goal of these initiatives is in creating developed, prosperous, peaceful and safe region. The achievement of this goal will have a positive impact on resolving the real problems of the EU itself: security, immigration problems, demographic changes, organized crime and terrorism.

In order to avoid perception of their activities as interference in internal affairs, the EC structures pay much attention to gradualism, activities within the existing institutions, focus on not changing political regimes, but on reforms from inside, as well as on active consultations with «our partners», and coordination with the USA, UNO and other external subjects. When it comes to such an important issue for the population as democracy, they use concepts, which are related more to the supremacy of law and human rights [9].

Definitely there are some concerns about Islamists' participation in the process of political reform. Some European politicians stand for their exclusion or control in order to maintain stability in the region. They consider that Islamists are not true democrats, but only use democratic opportunities to win elections and religious feelings of their Muslim electorate. After coming to power they will use the legislative process to change the rules of the game and limit social and private freedoms.

Political regimes under the guidance of Islamists pose a threat to relations with the West and to peace in the region. Therefore at this stage it is required to make a clear difference between militant and moderate Islamists, who committed to non-violence and constitutional and legal means. The first ones are definitely in the minority among Islamist organizations and lack of support, while the latter are the majority and establish the main trends in Islamic movements. 
In this aspect the idea of Jurgen Habermas is interesting. It is about distinction of possibilities, provided by liberal and democratic states in post-secular society to overcome mutual uncontrolled mistrust and restore communications: «Liberal state provides freedom of religion as a civil right, thus religious minorities are no longer in a position of the tolerant and dependent on the favor of any more or less tolerant state power. But only democratic state allows a non-party application of this principle... Convincing criteria to determine, what should be tolerated, and what should not be tolerated, can be revealed only with deliberative and inclusive methods of democratic declaration of the will (i.e. by general discussion)» [6].

Only a democratic state is able to promote formation of post-secular political culture, stipulating equal participation in political life not only for representatives of dominating culture, but also for subcultures. «Muslim immigrants, J. Habermas states, can be integrated in the Western society not contrary to their religion, but together with it» [6].

But this religion should be inevitably transformed, possibly, there will be EuroIslam, characterized by reflexive consciousness (ability to see themselves through the eyes of others). Having an opportunity to state religious opinions on political matters, saving commitment to own religious communities, representatives of religious subcultures will have to accept the legitimacy of the state, which applies exclusively secular language in activities of its bodies.

Compared with Jurgen Habermas, Rowan Williams, the Head of Anglican Church of the Great Britain, went far beyond in 2008. He proposed to include Sharia elements in the British legal system to establish coexistence with Muslim communities. The idea is in reducing the sphere of universal law, supported by the state and obligatory for all citizens. The volume of direct prohibitions and guaranteed citizen right should be the same, but it will possible to utilize not all of the rights, but only those, which comply with the moral principles of an individual citizen. All other matters can be regulated within the coexisting and competing with each other moral-legal systems of different social groups, integrated as religious communities. By this it is proposed to decline the universalist ideology and implement a post-secular by its character return of morality to the law by offering citizens to refer to the market of different moral values (Christian, Judaic, Islamic, etc.). This step could contribute to including a part of Sharia provisions to the British legal system. At the same time R. Williams underlines, that he is not an adherent of a complete integration of Sharia and first of all those of its inhumane sanctions, which are in practice in various countries [1].

This event became possible only under the conditions of post-secular stage of development of British society, which consists of social groups with different moral principles. Dialogue of different cultures, including legal culture, can be realized through recognizing their significant specificity. Such postmodern and post-secular perception of society may help to overcome the existing stereotypes in relation to Islam and Muslim society.

Contradictions in the views of J. Habermas and R. Williams reflect the disputes of adherents of two approaches to integration of Muslims in Western societies: 1) secular 
and liberal versions of advisory democracy; 2) democratic model of multicultural jurisdiction. Pluralist democracy of post-secular society makes multicultural jurisdiction possible. Post-secularism is related with the concept of plurality of modernizations, stipulating various (secular and religious) ways of modernization. This approach was expressed in proposals of R. Williams. In fact he proposed to include religion in public sphere, to equalize secular and religious law, religious and irreligious citizens, along with parliamentary recognition of the lawmaking power of a number of civil society structures (religious and professional organizations, ethno-religious minorities) [8].

Both in the UK, and in Russia sharp criticism of Williams' proposal is conducted by adherents of secularism, who state, that it means a complete destruction of the Britain identity, official capitulation of Christianity, recognizing a failure of multiculturalism policy, undermining the secular foundations of society, dividing the country into different religious and ethnic communities [3. P. 88].

Nevertheless developing R. Williams' opinion, some Russian authors propose not less radical solution to change the Western morality and legal system taking into account a part of Muslim principles, which are close to the Christian ideals, forgotten by the modern society of market fundamentalism with its values of profit and personal wellbeing. This proposition looks very conservative as a fundamentalist return to the Christian values, but only with this pragmatic policy it is possible to save civilization by means of finding a common language with the Muslims, living in the West and rejecting its values [14].

Russian society is also facing large-scale problems of integrating Muslims in the Post-Soviet state structure, business and civil society.

There are problems of legal regulation of relations between the state and Islam, among Islamic centers, social doctrine of Islam, Islamic influence on national relations, struggle against extremism and terrorism under Islamic slogans. The struggle against Islamic extremism with its complexity and actuality should not shade a more broad view of inevitably going integration of Islam in political life of the Russian society. The patterns of relations between the state and Islam as a religion, worked out during the PostSoviet period, fail when interacting with political Islam. It is required to search ways to use positive moral and institutional potential of Islam, develop democratic secular political regime, strengthen the state and law, and develop civil society. Along with hard legal and power opposition to extremism and terrorism, which use Islamic concepts, it is required to create an Islamic spiritual alternative to these phenomena, which will contribute to preservation and strengthening the constitutional system of Russia. It can (should) be done by Muslims with the ijtihad principle as one of the key concept of Islamic legal doctrine [20].

Such a problem is of course difficult for Russia as well as for any other non-Western society. Because it involves the spread of democracy into social groups that have no experience of liberal politics, interpret politics with terms of religious cultures, warily accept any Western ideas as a form of forced Westernization. Perhaps only use of existing traditional and creation of liberal institutions of civil society can bring tangible results in the near future. It is necessary to maximize the political culture and forms of demo- 
cracy, characteristic for non-Western civilizations. In modern Russia the will of the population in different regions may contribute to the creation of a number of models of civil society, taking into account the civic values (in pre secular, secular or post secular forms), traditions of democracy, existing level of civic engagement and economic development.

\section{REFERENCES}

[1] Archbishop - UK law needs to find accommodation with religious law codes. Available from: https://www.churchofengland.org/media-centre/news/2008/02/pr1308.aspx.

[2] Bukay D. Can There Be an Islamic Democracy? Review Essay. Middle East Quarterly. Spring 2007. Available from: http://www.meforum.org/1680/can-there-be-an-islamic-democracy.

[3] Chudinova E. There is no 'partial' Sharia. Profil. 2008; February 18 (in Russ.).

[4] Esposito J. Unholy War: Terror in the Name of Islam. Oxford: Oxford Univ. Press; 2002.

[5] Fukuyama F. The End of History and the Last Man. Moscow; 2007 (in Russ.).

[6] Habermas Ju. Notes on a post-secular society. Available from: http://www.signandsight.com/ features/1714.html.

[7] Hunter Sh.T. The Future of Islam and the West: Clash of Civilizations or Peaceful Coexistence? Westport, CT: Praeger Publishers; 1998.

[8] Kaul V. Introduction. Philosophy \& Social Criticism. Vol. 36; 3 - 4.

[9] Kausch Kr. Europe's Engagement with Moderate Islamists. Islamist Radicalisation: The Challenge for Euro-Mediterranean Relations. Edited by Michael Emerson, Kristina Kausch and Richard Young. Brussels: Centre for European Policy Studies, Madrid: FRIDE; 2009.

[10] Kaya I. Modernity, Openness, Interpretation: A Perspective on Multiple Modernities. Social Science Information. 2004; Vol. 43(1).

[11] Khatami M. Islam, Dialogue and Civil Society. Karachi: The Foundation for the Revival of Islamic Heritage; 2000.

[12] Kepel G. Jihad: Expansion et déclin de l'Islamisme. Moscow: Ladomir; 2004 (in Russ.).

[13] Klyuchnikov B.F. Islamism, USA and Europe. Moscow; 2003 (in Russ.).

[14] Lukin A. Will Sharia save Europe? Nezavisimaya Gazeta. 2008; March 20 (in Russ.).

[15] Malkovskaya I., Pochta Yu. Fundamentalism - Menace or Salvation. Social: roots, structural profiles, contemporary challenges. Ed. by P.K. Gretchko, E.M. Kurmeleva. Moscow: Russian Political Encyclopedia; 2009 (in Russ.).

[16] Mandaville P. Global Political Islam. London and New York: Routledge; 2007.

[17] Pipes D. Radical Islam as Its Own Antidote [Argues Reuel Gerecht]. 2005. Available from: http://www.meforum.org/4312/radical-islam-as-its-own-antidote-argues-reuel-gerecht.

[18] Pochta Yu. Post secular Society. Social: roots, structural profiles, contemporary challenges. Ed. by P.K. Gretchko, E.M. Kurmeleva. Moscow: Russian Political Encyclopedia; 2009 (in Russ.).

[19] Spohn W. Political Sociology: Between Civilizations and Modernities. A Multiple Modernities Perspective. European Journal of Social Theory. 2010; Vol. 13(1).

[20] Syukiyainen L. Russian Power and Islam. Otechestvennye zapiski. 2003; 5(14) (in Russ.).

[21] Tibi B. Islam as a Political Religion? Possibilities of inter-religious Pluralism in Conditions of Civilizations' Conflict. Neprikosnovennyi zapas. 2002; 6 (26) (in Russ.).

[22] Tibi B. The Challenge of Fundamentalism: Political Islam and the New World Disorder. Berkeley: Univ. of California Press; 2002.

[23] Wright R. Islam and Liberal Democracy: Two Visions of Reformation. Journal of Democracy. 1996; 7.2. Available from: http://www.journalofdemocracy.org/excerpts-robin-wright $\% \mathrm{E} 2 \%$ 80\%99s-1996-journal-democracy-article-\%E2\%80\%9Cislam-and-liberal-democracy-twovisions. 
DOI: $10.22363 / 2313-1438-2017-19-1-15-24$

\title{
МУСУЛЬМАНСКОЕ ОБЩЕСТВО МЕЖДУ ФУНДАМЕНТАЛИЗМОМ И ЛИБЕРАЛИЗМОМ: ПРОБЛЕМА ГРАЖДАНСКОГО ОБЩЕСТВА
}

\author{
Ю.М. Почта \\ Российский университет дружбы народов \\ ул. Миклухо-Маклая, 10/2, Москва, Россия, 117198
}

В статье рассматривается проблема формирования институтов гражданского общества в мусульманском мире в целом и в России как части мусульманского мира в частности. Эта проблема приобрела большое значение после завершения холодной войны, когда в условиях глобального доминирования либеральной демократии концепция гражданского общества была объявлена универсальной, способной обеспечить процесс модернизации. Автор исходит из того, что как практическая реализация, так и изучение процесса формирования гражданского общества в незападных обществах находятся под сильным влиянием отождествления институтов гражданского общества с западной постхристианской цивилизацией, с либеральной политической культурой. Однако исторический опыт показывает, что гражданское общество невозможно заимствовать из иного социального окружения. Оно может органично вырасти только на основе своей культуры. Автор делает вывод о том, что универсализация западного опыта и функционалистско-эволюционистские подходы к модернизации незападных обществ не способствуют анализу процесса формирования институтов гражданского общества. Для этого необходимы цивилизационный подход, исторический анализ культурных контекстов процессов модернизации, в том числе создания рыночной экономики, демократических политических режимов и гражданского общества. Современный постмодернистский дискурс дает возможность предположить цивилизационный плюрализм процессов политической модернизации. Ключевым в этих условиях является вопрос о специфике сосуществования обществ, находящихся на различных этапах социального развития. В частности, необходимо принимать во внимание возможное сосуществование ряда досекулярных культур (исламских и конфуцианских) с либеральной демократией как постсекулярным феноменом.

Ключевые слова: гражданское общество, цивилизация, демократия, либерализм, модернизация, постсекулярное общество, мусульманское общество, фундаментализм 